\title{
FLOORING CHARACTERISTICS OF THERMO-MECHANICAL DENSIFIED WOOD FROM THREE HARDWOOD TROPICAL SPECIES IN COSTA RICA
}

\author{
Carolina Tenorio ${ }^{1}$
}

https://orcid.org/0000-0003-2901-7079

Roger Moya ${ }^{2, *}$

https://orcid.org/0000-0002-6201-8383

Angel Navarro-Mora ${ }^{3}$

https://orcid.org/0000-0002-9814-0778

\begin{abstract}
Densification is one method used to modify low-density woods to make them achieve the hardness required for flooring application. The purpose of this study was to investigate the effect of thermo-mechanical densification with pre-heating in wood of Alnus acuminata, Vochysia ferruginea and Vochysia guatemalensis from, seeking to stabilize and reduce spring-back of the densified wood and evaluate its performance in flooring applications. The results showed that the wood of the three species turned dark. This is because brightness diminished and yellowness and redness increased. Weight loss due to pre-heating was statistically higher in $V$. ferruginea and $V$. guatemalensis. The final density and spring-back were statistically similar in the three species. The percentage of densification of $A$. acuminata and $V$. guatemalensis were statistically higher than for $V$. ferruginea and the degree of compression was statistically higher in $V$. guatemalensis. As for flooring evaluation, the percentage of densification, temperature and time of pre-heating affected the behavior of densified wood flooring. The low percentage of densification and high weight loss in the pre-heating stage caused greater values of wear, wear index, residual deformation, residual indentation for the falling ball indentation test, and more damages in the surface indentation test in wood of $V$. ferruginea.
\end{abstract}

Keywords: Densification, Flooring properties, low density, spring-back, tropical species, wear index.

\section{INTRODUCTION}

Wood as a constructive element is aesthetically pleasing, provides thermal isolation and mechanical resistance (Blanco-Flórez et al. 2015). However, compared to other materials used for flooring, wood suffers damage caused by objects, wear from abrasive elements and people traffic, among others (Blanchet et al. 2003). The main factor when choosing wood for flooring is its specific gravity (SG) (Zhou et al. 2019). There is a high correlation between SG and its mechanical properties; high SG provides enhanced mechanical resistance, therefore improved hardness (Sadatnezhad et al. 2017). For this reason, solid wood from high SG species has been widely used for flooring, but the species must be presented adequate ratio of shrinkage (Feifel

\footnotetext{
'Instituto Tecnológico de Costa Rica, Escuela de Ingeniería Forestal, Cartago, Costa Rica. ctenorio@itcr.ac.cr

${ }^{2}$ Instituto Tecnológico de Costa Rica, Escuela de Ingeniería Forestal, Cartago, Costa Rica.

${ }_{3}^{3}$ Instituto Tecnológico de Costa Rica, Escuela de Ingeniería en Construcción, Cartago, Costa Rica. anavarro@itcr.ac.cr

•Corresponding author: rmoya@itcr.ac.cr

Received: 29.03.2020 Accepted: 17.11.2020
} 
et al. 2015).

In Costa Rica, wood with SG above 0,7 has been used for flooring (United States. Office of Inter-American Affairs 1943). Currently, however, the woods commonly used for flooring are banned, listed as endangered, or threatened (Moya et al. 2013). As a result, prices of these woods are high, which promotes the importation of woods or wood-based products to satisfy the demand of this sector (Serrano and Moya 2011). This has led to the search for new options to replace high SG woods with lower SG woods produced in fast-growing forest plantations (Nölte et al. 2018). A. acuminate ( $\mathrm{SG}=0,34)$, $V$. ferruginea $(\mathrm{SG}=0,37)$ and $V$. guatemalensis $(\mathrm{SG}=0,32)$ are among the forest plantations species used in Costa Rica, the three of them are fast-growing hardwood species (Moya 2018) with low SG woods, considered in the market as easy-to-work softwoods (Tenorio et al. 2016). Because of their low SG, the mechanical properties of these woods are also low, therefore not convenient for structural uses, but for products with low structural demand in low commercial value markets (Serrano and Moya 2011).

On the other hand, the densification process makes it possible for low or moderate SG woods to replace high density species by modifying them to meet the hardness requirements necessary for some uses, such as flooring (Fang et al. 2012). There are several densification processes, generally consisting of the following stages: (i) soften the structure of the wood by using temperatures between $150{ }^{\circ} \mathrm{C}-200{ }^{\circ} \mathrm{C}$ and convenient moisture contents; (ii) compress the wood by means of two metal plates and (iii) stabilize and keep the deformation obtained in the wood (Sandberg et al. 2013).

Thermo-mechanical densification is the simplest densification method. It reduces the empty spaces of the wood cells, called the lumen, through the joint action of heat and radial compression (Navi and Heger 2004). Thermomechanical densification gives some enhanced mechanical properties to the compressed wood, but the compression set is unstable, and wood tends to recover its original shape even after large deformation, especially under conditions of high humidity and high temperature (Navi and Heger 2004, Sadatnezhad et al. 2017). This phenomenon is known as spring-back.

The permanent fixation of large deformation as a result of compression is very important for densified wood to be utilized as an engineering material (Inoue et al. 2008), especially for flooring applications. Many studies have been conducted regarding stabilization of compressed wood, with techniques such as impregnation with resins and physical or chemical treatments (Inoue et al. 1993, Kutnar and Kamke 2012, Pelit et al. 2016). Among these techniques, physical treatments are preferred, such as steaming or heating, since they do not require any chemicals (Darwis et al. 2017). Heating and/or steaming before compression have been found to reduce densified wood spring-back significantly (Inoue et al. 2008, Darwis et al. 2017). However, heat treatments have the disadvantage of reducing the strength properties of the wood due to weight loss and chemical degradation of wood, when it exposed to high temperatures (Perçin et al. 2015).

Densification of wood from forest plantations in Costa Rica has been successfully tested in A. cuminata, $V$. ferruginea and V. guatemalensis wood (Tenorio and Moya 2020, Tenorio and Moya 2021, Tenorio et al. 2020). In addition to adapting to the densification process (Tenorio and Moya 2020), the characteristics of the densified wood of these species are appropriate and comparable to those of other high SG tropical woods (Tenorio and Moya 2020, Tenorio and Moya 2021). However, the inconvenient found is that the treatment used in the initial stage of the process - heating and steaming for 10 minutes between two metal plates - is that it produces low dimensional stability and high spring-back in the densified wood obtained (Tenorio and Moya 2020), making it unsuitable for flooring application.

Thus, the objective of the present study was to investigate the effect of densification using pre-heating on stabilization and spring-back reduction of densified wood; then, evaluate the behaviour of this wood in a flooring application. A. acuminata, V. ferruginea and $V$. guatemalensis woods were used and variables specific to the densification process (final density, degree of compression, percentage of densification, spring-back and color change), as well as the wood characteristics for flooring application (compression shear strength of the glue line, resistance to abrasion, resistance to indentation by the falling ball, concentrated loading and surface indentation), were analysed. The results obtained will provide key information to make these species with low values in mechanical properties suitable to produce new high-performance wood products such as flooring. 


\section{MATERIALS AND METHODS}

\section{Origin and characteristics of the wood before densification}

A. acuminata, $V$. ferruginea and $V$. guatemalensis woods coming from fast growing forest plantations in Cartago and Alajuela in Costa Rica were tested. The trees used were around 8 years old. The wood used was mostly sapwood, as trees this age generally present low heartwood content (Tenorio et al. 2016). Fifty wood samples $300 \mathrm{~mm}$ long x $70 \mathrm{~mm}$ wide and $20 \mathrm{~mm}$ thick were prepared from each species. The dimensions (length, width and thickness), density and moisture content of each sample were determined previous to densification (Table 1). The density was calculated by the ratio of weight and volume, measuring the initial thickness, initial width and length. The moisture content was calculated as the ratio of the initial weight and dry oven weight, expressed as a percentage according to ASTM D-4442-16 (2016).

Table 1: Thickness, density and moisture content of the wood samples before densification.

\begin{tabular}{|c|c|c|c|}
\hline Species & A.acuminata & V. ferruginea & V. guatemalensis \\
\hline Specific gravity* & 0,34 & 0,37 & 0,32 \\
\hline Initial thickness $(\mathrm{mm})$ & $19,88(0,41)$ & $19,88(0,38)$ & $20,05(0,32)$ \\
\hline Initial wood density $\left(\mathrm{g} / \mathrm{cm}^{3}\right)$ & $0,42(0,03)$ & $0,45(0,05)$ & $0,42(0,06)$ \\
\hline Initial moisture content $(\%)$ & $10,75(0,33)$ & $10,99(0,26)$ & $10,87(0,67)$ \\
\hline
\end{tabular}

Values in parenthesis mean standard deviation.

* Data from Tenorio et al. (2016)

The initial colour of the wood before densification was also determined by means of a HunterLab Mini Scan XE Plus spectrophotometer, CIEL*a*b* system (Table 1). The range of this measurement is from 400 to $700 \mathrm{~nm}$ with an opening at the point of measurement of $11 \mathrm{~mm}$. For the observation of reflection, the specular component (SCI model) was included at a $10^{\circ}$ angle, which is normal for the specimen surface (D65/10); a field of vision of $2^{\circ}$ (Standard observer, CIE 1931) and an illumination standard of D65 (corresponding to daylight in $6500 \mathrm{~K}$ ). The mini Skan XE Plus generated three parameters for each measurement, namely: L* (luminosity), $a^{*}$ (the tendency of color from red to green), and finally $b^{*}$ (the tendency of color from yellow to blue).

\section{Densification process}

The densification process for the three species consisted of three stages: stage 1, heating, where heat was applied to the wooden samples in a closed system for 60 minutes, for A. acuminata and $V$. guatemalensis a temperature of $180^{\circ} \mathrm{C}$ was used and for $V$. ferruginea of $160^{\circ} \mathrm{C}$. Stage 2 , compression, where the samples were compressed perpendicularly to the grain until reaching the target thickness of $9 \mathrm{~mm}(55 \%$ degree of compression) for 15 minutes keeping the temperature used in stage 1 (heating) of the process. Stage 3 , stabilization, where the samples were kept pressed and heated but without load for 10 more minutes. After densification, the samples were placed into an oven at $103{ }^{\circ} \mathrm{C}$ for 24 hours. In total, 50 samples were densified per species.

The differences in temperature for $V$. ferruginea in comparison with the other two species are because that when carrying out the first tests with $180^{\circ} \mathrm{C}$ the surface of the wood samples burned and, in some cases, parts adhered to the metal plates, making it impossible the evaluation of the process. Because of that it was decided to work with a different temperature for this species.

\section{Evaluation of the densification process}

At the end of stage 1 (heating) wood weight loss was calculated as the ratio between the initial weight of the wood and the weight after stage 1, expressed as a percentage of the initial weight. This ratio includes the lost water vapor that can be evaporated. Besides, the wood colour was determined as described above.

During the densification process, the thickness of each wood sample was determined at finalizing stages 2 and 3 (compression and stabilization thickness). After the densification process the dimensions, weight, 
colour, density and percentage of densification of each sample were determined. For colour measurement the same procedure used before densification was utilized. Two colour changes $\left(\Delta \mathrm{E}^{*}\right)$ were observed, the first after stage 1 (heating), which was called heating $\Delta \mathrm{E}^{*}$, and the second after finishing the densification process (after placing the samples into the oven for 24 hours), called densification $\Delta \mathrm{E}^{*}$. The density was calculated as the ratio between weight and volume of the wood sample after stage 3 (stabilization). For volume, the sample's dimensions (stabilization thickness, length and width) were determined. The percentage of densification was calculated as the relation between the initial density and the density of the densified sample.

The thicknesses determined in stages 2 and 3 (compression and stabilization thickness), were used to determine the degree of compression and the spring-back of the sample thickness. The degree of compression was calculated as the ratio between the initial thickness and the compression thickness, expressed as a percentage. The spring-back of the thickness of the densified wood was calculated as the absolute value of the ratio between the compression thickness and the stabilization thickness, also expressed as a percentage.

\section{Flooring evaluation}

In the evaluation of the densified wood flooring, the shear strength of the glue line was determined for two densified pieces glued with an adhesive used to glue flooring, following the norm ASTM D905-08 (2013). Twenty samples per species bonded with Advantage EP-950A from Franklin Adhesives Polymers (Franklin Division, Columbus, Ohio, USA) were prepared.

Abrasion resistance was determined according to ASTM D4060-14 (2014). Three square samples of 100 $\mathrm{mm}$ at the densified thickness were used and the wear index was determined by Equation 1:

$$
I=(A-B) * \frac{1000}{C}
$$

Where: $\mathrm{I}=$ wear index, $\mathrm{A}=$ weight of test specimen before abrasion $(\mathrm{mg}), \mathrm{B}=$ weight of test specimen after abrasion ( $\mathrm{mg}$ ) and $\mathrm{C}=$ number of cycles of abrasion recorded.

Three indentation tests using the densified wood and following ASTM D2394-17 (2017), were performed: i) falling ball indentation, ii) concentrated loading and iii) surface indentation. i) Falling ball indentation was performed using 9 samples per species with seven different heights ranging from $122 \mathrm{~cm}$ to $213 \mathrm{~cm}$ at $15 \mathrm{~cm}$ intervals. ii) Concentrated loading test were performed on 3 boards $457 \mathrm{~mm}^{2}$ of the densified wood from each species glued on a $19 \mathrm{~mm}$ thick structural plywood. As support for the boards 3 pieces of Gmelina arborea were used, with dimensions of $5 \mathrm{~cm} \times 7,5 \mathrm{~cm}$ x length of the lower side of the board, one at each side and one on the centre of the board. Two loading points were used for each board according to the ASTM D2394-17 (2017). The residual deformation and the maximum deformation in a load vs. deformation plot for each species were determined. iii) Surface indentation test was performed using a sample comprised of two densified pieces; one beside the other placed on $19 \mathrm{~mm}$ thick structural plywood, totaling 6 samples per species. For each test the percentage of samples completely, severe, or moderately damaged was determined, according to ASTM D2394-17 (2017).

\section{Statistical analysis}

Measured variables complied with the assumptions of normal distribution and homogeneity of variance. The presence of outliers was also verified. An analysis of variance was performed to verify the effect of wood species on parameters of the densification process i.e. wood color before and after heating, heating $\Delta \mathrm{E}^{*}$, densification $\Delta \mathrm{E}^{*}$, weight loss after heating, final density, percentage of densification, degree of compression and spring-back and flooring parameters (shear strength of the glue line and residual deformation for concentrated loading test). The analysis of variance and Tukey tests were performed with the SAS software (SAS Institute Inc., Cary, NC). The category variables measured in flooring (wear index and surface indentation) were not applied to any statistical test. 


\section{RESULTS}

\section{Densification process}

In this study, high temperatures $\left(180^{\circ} \mathrm{C}\right.$ for $A$. acuminata and $V$. guatemalensis and $160{ }^{\circ} \mathrm{C}$ for $V$. ferruginea $)$ produced changes in the color parameters during densification (Table 2). After stage 1 (heating) brightness $\left(\mathrm{L}^{*}\right)$ and yellowness ( $\mathrm{b}^{*}$ ) decreased in the three species and redness ( $\mathrm{a}^{*}$ ) decreased in A. acuminata and $V$. ferruginea wood (Table 2). After densification, at the end of stage 3, the parameter brightness $\left(\mathrm{L}^{*}\right)$ decreased in the three species, while yellowness $\left(\mathrm{b}^{*}\right)$ and redness $\left(\mathrm{a}^{*}\right)$ increased in the three species (Table 2 ). Heating $\Delta \mathrm{E}^{*}$ (color change after heating and before compression) was greater than densification $\Delta \mathrm{E}^{*}$ (color change after stage 3) for the three species (Table 2). A. acuminata and $V$. ferruginea woods presented heating $\Delta \mathrm{E}^{*}$ statistically higher compared to $V$. guatemalensis wood (Table 2), in contrast with densification $\Delta \mathrm{E}^{*}$, where $V$. guatemalensis wood showed the statistically higher value (Table 2).

Weight loss after stage 1 (heating) was statistically higher in $V$. ferruginea and $V$. guatemalensis woods compared to $A$. acuminata wood (Table 2). Concerning to the final density, no differences were observed among the woods of the three species (Table 2). The percentage of densification in A. acuminata and V. guatemalensis woods was statistically higher than in V. ferruginea wood (Table 2), while the degree of compression was statistically higher for $V$. guatemalensis wood (Table 2). Regarding wood spring-back after densification, no statistical differences among species were observed (Table 2).

Table 2: Characteristics of wood samples after the densification.

\begin{tabular}{|c|c|c|c|c|}
\hline \multicolumn{2}{|c|}{ Parameters } & A.acuminata & V. ferruginea & V.guatemalensis \\
\hline \multirow{2}{*}{$\begin{array}{c}\text { Wood color parameter } \\
\text { before heating }\end{array}$} & $\mathrm{L}^{*}$ & $67,66^{\mathrm{C}}(2,47)$ & $73,63^{\mathrm{A}}(4,22)$ & $70,82^{\mathrm{B}}(2,48)$ \\
\cline { 2 - 5 } & $\mathrm{a}^{*}$ & $10,73^{\mathrm{A}}(1,37)$ & $8,78^{\mathrm{C}}(1,90)$ & $9,93^{\mathrm{B}}(1,55)$ \\
\cline { 2 - 5 } & $\mathrm{b}^{*}$ & $22,38^{\mathrm{A}}(2,40)$ & $16,96^{\mathrm{C}}(1,56)$ & $21,40^{\mathrm{B}}(1,51)$ \\
\hline \multirow{3}{*}{$\begin{array}{c}\text { Wood color parameter } \\
\text { after heating }\end{array}$} & $\mathrm{L}^{*}$ & $60,93^{\mathrm{B}}(2,49)$ & $65,06^{\mathrm{A}}(4,63)$ & $64,45^{\mathrm{A}}(3,27)$ \\
\cline { 2 - 5 } & $\mathrm{a}^{*}$ & $6,49^{\mathrm{B}}(0,75)$ & $6,13^{\mathrm{B}}(1,44)$ & $10,03^{\mathrm{A}}(1,52)$ \\
\cline { 2 - 5 } & $\mathrm{b}^{*}$ & $15,95^{\mathrm{B}}(1,84)$ & $16,03^{\mathrm{B}}(1,18)$ & $21,24^{\mathrm{A}}(0,85)$ \\
\hline \multirow{2}{*}{$\begin{array}{c}\text { Wood color parameter } \\
\text { after densification }\end{array}$} & $\mathrm{L}^{*}$ & $60,01^{\mathrm{C}}(2,08)$ & $64,89^{\mathrm{A}}(4,34)$ & $62,14^{\mathrm{B}}(3,38)$ \\
\cline { 2 - 5 } & $\mathrm{a}^{*}$ & $6,72^{\mathrm{A}}(0,52)$ & $6,84^{\mathrm{A}}(1,66)$ & $11,39^{\mathrm{B}}(1,61)$ \\
\cline { 2 - 5 } & $\mathrm{b}^{*}$ & $16,00^{\mathrm{C}}(1,52)$ & $16,93^{\mathrm{B}}(1,22)$ & $21,68^{\mathrm{A}}(0,71)$ \\
\hline \multicolumn{2}{|c|}{ Heating $\Delta \mathrm{E}^{*}$} & $10,36^{\mathrm{A}}(3,01)$ & $9,27^{\mathrm{A}}(3,21)$ & $6,33^{\mathrm{B}}(2,18)$ \\
\hline \multicolumn{2}{|c|}{ Densification $\Delta \mathrm{E}^{*}$} & $1,69^{\mathrm{B}}(1,45)$ & $1,87^{\mathrm{B}}(0,82)$ & $2,99^{\mathrm{A}}(1,63)$ \\
\hline \multicolumn{2}{|c|}{ Weight loss after heating $(\%)$} & $11,80^{\mathrm{B}}(0,37)$ & $12,16^{\mathrm{A}}(0,43)$ & $12,03^{\mathrm{A}}(0,54)$ \\
\hline \multicolumn{2}{|c|}{ Final density $\left(\mathrm{g} / \mathrm{cm}^{3}\right)$} & $0,71^{\mathrm{A}}(0,06)$ & $0,72^{\mathrm{A}}(0,08)$ & $0,69^{\mathrm{A}}(0,08)$ \\
\hline Percentage of densification $(\%)$ & $41,61^{\mathrm{A}}(2,57)$ & $37,71^{\mathrm{B}}(3,96)$ & $40,10^{\mathrm{A}}(3,33)$ \\
\hline \multicolumn{2}{|c|}{ Degree of compression $(\%)$} & $53,04^{\mathrm{B}}(1,40)$ & $52,33^{\mathrm{B}}(1,68)$ & $53,86^{\mathrm{A}}(1,90)$ \\
\hline \multicolumn{2}{|c}{ Spring-back $(\%)$} & $5,61^{\mathrm{A}}(4,24)$ & $3,62^{\mathrm{A}}(4,06)$ & $3,76^{\mathrm{A}}(4,33)$ \\
\hline
\end{tabular}

Different letters for each parameter denote statistical differences between treatments (level of significance 0,05 ). Values in parentheses are standard deviation.

\section{Flooring evaluation}

In the flooring evaluation of the densified wood of the three species, the shear stress by compression loading was statistically higher in $A$. acuminata wood relative to $V$. ferruginea and $V$. guatemalensis woods (Table 3). In relation to resistance to abrasion, although no statistical analysis was performed, the wear index of densified wood of $V$. ferruginea presented the highest value, while $A$. acuminata and $V$. guatemalensis densified wood showed the lowest values, between 0,04 and 0,05 (Table 3).

For the indentation tests, in the concentrated loading test, no differences were observed between densified wood of the three species in the residual deformation (Table 3). Figure 1a, Figure1b, Figure1c present the load vs. deformation curves obtained for the wood of the three species in the concentrated loading test. In the case 
of $A$. acuminata densified wood, the deformation observed when applying a load of $500 \mathrm{~kg}$ was $8,34 \mathrm{~mm}$ on average (Figure 1a). For $V$. ferruginea the deformation was $8,50 \mathrm{~mm}$ on average (Figure 1b), while for $V$. guatemalensis deformation of the densified wood was 7,54 $\mathrm{mm}$ on average (Figure 1c).

Table 3: Results of flooring tests for the densified wood of the three species.

\begin{tabular}{|c|c|c|c|c|}
\hline \multicolumn{2}{|c|}{ Parameter } & A.acuminata & $V$. ferruginea & V.guatemalensis \\
\hline \multicolumn{2}{|c|}{ Glue line shear strength (MPa) } & $6,20^{\mathrm{A}}(1,98)$ & $3,61^{\mathrm{B}}(0,80)$ & $2,93^{\mathrm{B}}(0,83)$ \\
\hline \multicolumn{2}{|c|}{ Wear index $(g)$} & 0,04 & 0,12 & 0,05 \\
\hline \multicolumn{2}{|c|}{$\begin{array}{c}\text { Residual deformation for } \\
\text { concentrated loading test (mm) }\end{array}$} & $1,14^{\mathrm{A}}(0,39)$ & $1,18^{\mathrm{A}}(0,36)$ & $1,26^{\mathrm{A}}(0,70)$ \\
\hline \multirow{3}{*}{$\begin{array}{l}\text { Surface indentation } \\
\text { ( } \% \text { of samples) }\end{array}$} & Moderate & 50,00 & 50,00 & 50,00 \\
\hline & Severe & 33,33 & 16,66 & 33,33 \\
\hline & Complete & 16,66 & 33,33 & 16,66 \\
\hline
\end{tabular}

Different letters for each parameter denote statistical differences between treatments (level of significance 0,05 ). Values in parentheses are standard deviation.
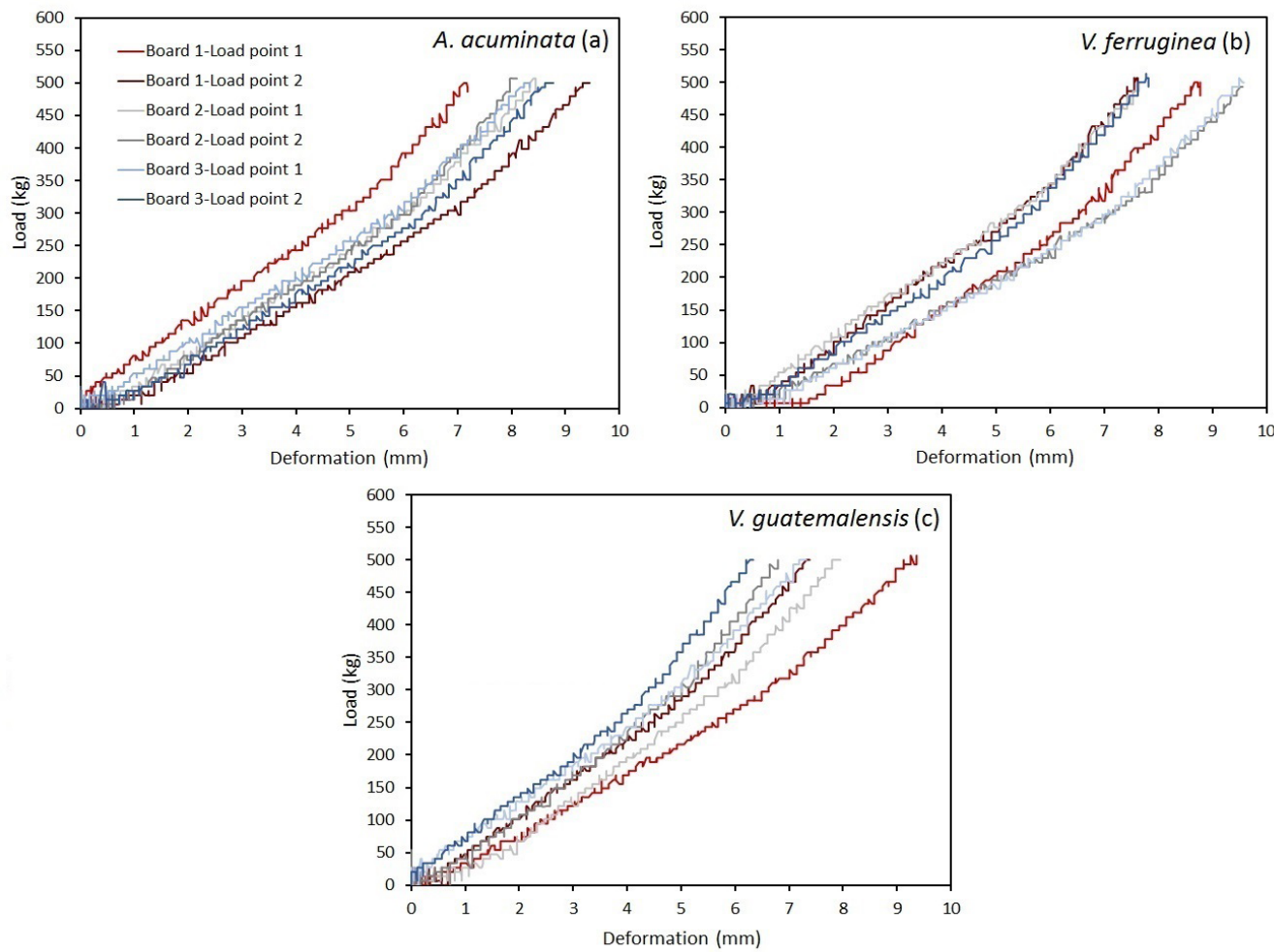

Figure 1: Load vs. deformation for (a) A. acuminata, (b) V. ferruginea and (c) V. guatemalensis.

As for the falling ball indentation test, the values of residual indentation vs. drop height for the three species were plotted in Figure 2. The densified wood of the three species showed an increase in the residual indentation with increasing drop height. Such behaviour was more evident in densified wood of $V$. guatemalensis. As for densified wood of $A$. acuminata, with $122 \mathrm{~cm}$ drop height the residual indentation was $0,043 \mathrm{~mm}$, while with $213 \mathrm{~cm}$ drop height it was $0,077 \mathrm{~mm}$. For $V$. ferruginea the residual indentation increased from $0,067 \mathrm{~mm}$ with $122 \mathrm{~cm}$ drop height to $0,085 \mathrm{~mm}$ with $213 \mathrm{~cm}$ drop height. On the other hand, in $V$. guatemalensis the residual indentation increased from $0,047 \mathrm{~mm}$ with $122 \mathrm{~cm}$ drop height to $0,089 \mathrm{~mm}$ with $213 \mathrm{~cm}$ drop height (Figure 2). Moreover, V. ferruginea presented values of residual indentation higher than those of the other two species in most drop heights, except for drop heights 198 and $213 \mathrm{~cm}$, where V. guatemalensis presented the 
greatest values.

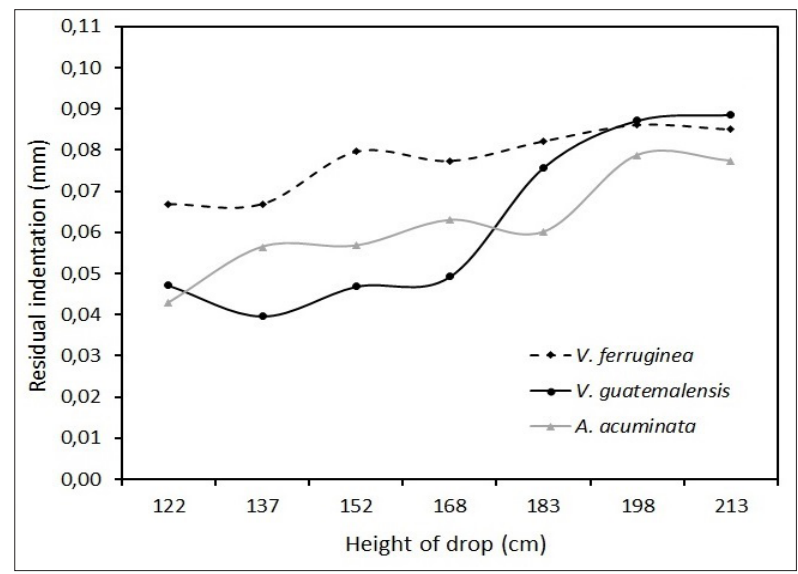

Figure 2: Residual indentation vs. drop height plotting for falling ball indentation test for the densified wood of the three species.
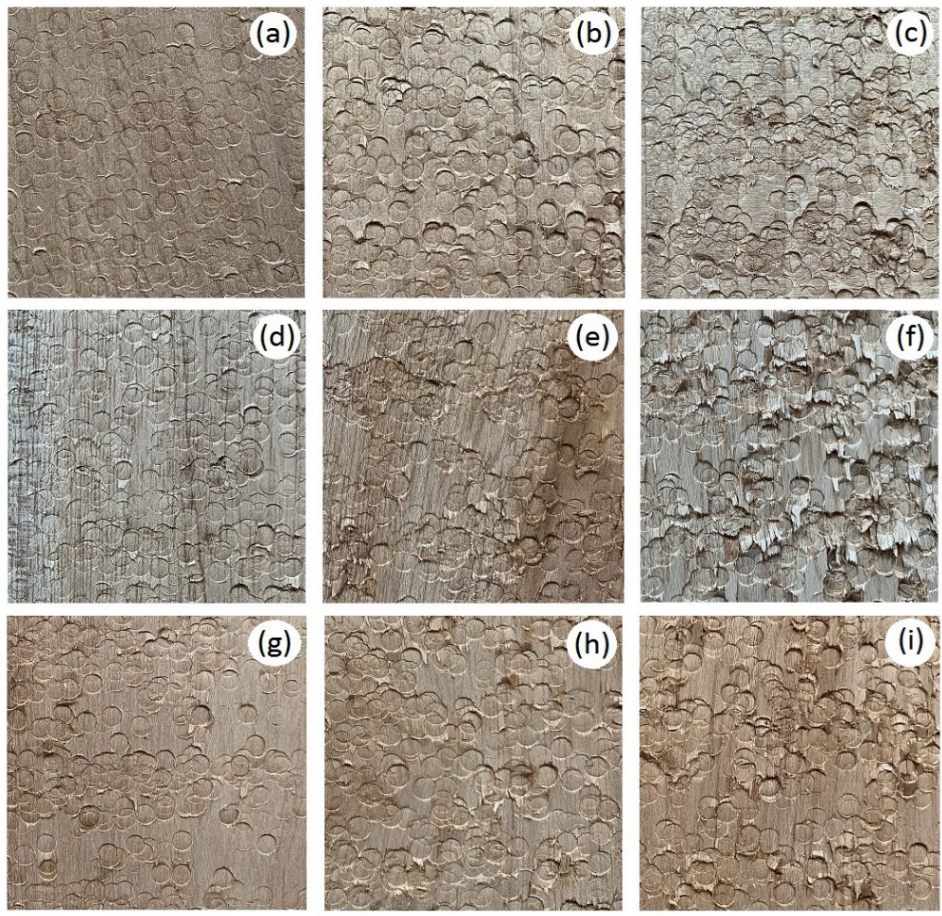

Figure 3: Moderate, severe and complete surface indentation of the densified wood; A. acuminata ((a), (b) and (c), respectively), V. ferruginea ((d), (e) and (f), respectively) and V. guatemalensis ((g), (h) and (i), respectively).

In the surface indentation test, the three species presented moderate, severe and complete damages. As for A. acuminata and $V$. guatemalensis, $50 \%$ of the densified wood samples sowed moderate damage (Figure $3 \mathrm{a}$ and Figure 3g), while 33,33\% presented severe damage (Figure $3 \mathrm{~b}$ and Figure $3 \mathrm{~h}$ ) and only 16,66\% showed complete damage (Figure $3 \mathrm{c}$ and Figure 3i) (Table 3). As for V. ferruginea, $50 \%$ of the samples showed moderate damage (Figure 3d); 16,66\% showed severe damage (Figure 3e) and 33,33\% complete damage (Figure 3f) (Table 3). 


\section{Discussion}

\section{Densification process}

Color is an important aesthetic feature in wood derived products (Jalilzadehazhari and Johansson 2019), particularly if intended for flooring (Nordvik et al. 2009). Here, because high temperatures were applied (180 ${ }^{\circ} \mathrm{C}$ for A. acuminata and $V$. guatemalensis wood and $160{ }^{\circ} \mathrm{C}$ for $V$. ferruginea wood) during the densification process, changes were observed in the color parameters of the wood of the three species (Table 2). Visually, these changes were perceived in the form of wood darkening caused by the decrease in the parameter L*. The darkening of the densified wood is attributed to the temperature (Salca et al. 2016), since it affects the wood's chemical composition (Pohleven et al. 2019). Color changes in the densified wood are caused by hydrolysis of the hemicelluloses (Candelier et al. 2016), and reduction of lignin, which is associated with the production of chromophore groups (Salca et al. 2016), and change to a darker color at high temperatures (Table 2). Hydrolysis of the hemicelluloses produces changes in parameter $\mathrm{L}^{*}$, while reduction of lignin produces changes mainly in parameter a* (Moya et al. 2012), which was reflected in parameters $\mathrm{L}^{*}$ and $\mathrm{a}^{*}$, respectively, in the present study (Table 2). However, Matsuo et al.(2010) indicate that wood darkening resulting from a thermal treatment is due to the reduction of the parameter luminosity $\mathrm{L}^{*}$ instead of the change in parameter $\mathrm{a}^{*}$. Therefore, in this study the behaviour of parameter a* disagrees with what Matsuo et al. (2010) point out.

Regarding color change $\left(\Delta \mathrm{E}^{*}\right)$, the $\Delta \mathrm{E}^{*}$ obtained after stage 1 (heating $\Delta \mathrm{E}^{*}$ ) of the process was approximately 3 times greater than color changes after finalizing the densification process (densification $\Delta \mathrm{E}^{*}$ ) for the three species (Table 2). The time of exposure to temperature in the stages of the process explains this difference. The exposure time for heating $\Delta \mathrm{E}^{*}$ was 60 minutes, while for densification $\Delta \mathrm{E}^{*}$ it was only 25 minutes, corresponding to stages 2 and 3 of the process. According to Matsuo et al. (2010) the values of $\Delta \mathrm{E}^{*}$ increased logarithmically with the exposure time of the wood: the longer the exposure time, the greater the $\Delta \mathrm{E}^{*}$. The same authors indicate that the changes are cumulative, which means that the total $\Delta \mathrm{E}^{*}$ of the wood is given by the sum of de heating $\Delta \mathrm{E}^{*}$ and densification $\Delta \mathrm{E}^{*}$.

The thermo-mechanical densification process developed in this study allowed obtaining values without statistical difference between the three species in relation to the final density of the densified wood. Nevertheless, as expected, differences were observed regarding the percentage of densification. V. ferruginea wood presented the highest initial density $\left(0,45 \mathrm{~g} / \mathrm{cm}^{3}\right)$ but the lowest percentage of densification (Table 2) compared to $A$. acuminata and $V$. guatemalensis wood, which had lower initial density (Table 1 ) and higher percentages of densification (Table 2). To this respect, Tenorio and Moya (2021) point out that there is a high negative correlation between the initial density of the wood and the percentage of densification obtained, as confirmed in the present study's analysis of the three species.

As for the spring-back values obtained in this study, from 3,62 to 5,61\% (Table 2), they are much lower than those obtained for the same species using a thermo-hydro-mechanical densification process, where the spring-back obtained was greater than $10 \%$ for all three species (Tenorio and Moya 2020). The reduction in spring-back in this study is attributed to the heating time (stage 1) of 60 minutes, while in the previous study (Tenorio and Moya 2020) the heating time was 10 minutes. Spring-back reduction in this process results in greater stability of the densified wood (Inoue et al. 2008), which is ideal for flooring applications.

According to Sadatnezhad et al. (2017), time and temperature influence greatly wood fixation and can reduce spring-back. An increase in time during the heating stage, as occurred in the present study, increases the compression of wood and reduces the level of stress stored in the wood during densification. In addition, an increase in heating time affects the chemical composition of the wood (Inoue et al. 2008), because heating the wood to temperatures above $180{ }^{\circ} \mathrm{C}$ leads to degradation of components of hemicellulose and as a result, the stresses stored in the micro fibrils would be released (Norimoto et al. 1993, Dwianto et al. 1996) and the lignin will soften and flow to fill the space matrix that is in the wood fixing the wood dimensional stability (Darwis et al. 2017).

Inoue et al. (2008) also point out the importance of the adequate use of time and temperature as a treatment to increase the stability of densified wood. These authors indicate that there is a high correlation between the percentage of weight loss during the heating stage (stage 1 of the densification process) and wood springback, which is caused by loss of water and degradation of hemicelluloses during this stage. This behaviour was observed in the three species in this study. The determination of the weight loss of the samples (Table 2) demonstrated that the samples that presented more weight loss ( $V$. ferruginea and $V$. guatemalensis) also showed less spring-back (Table 2). Hence, it can be affirmed that 60 minutes in stage 1 of the densification pro- 
cess increase the stability of densified wood of the three tropical species used by reducing wood spring-back.

\section{Flooring evaluation}

The values of shear strength in the glue line obtained for densified wood in the flooring evaluation, from 2,93 $\mathrm{MPa}$ to 6,20 $\mathrm{MPa}$ (Table 3), are comparable to those obtained for solid wood glued with polyvinyl acetate (PVAc) wood adhesives, but inferior to values obtained with urea formaldehyde (UF) wood adhesives. For example, Moya et al .(2015) in nine tropical woods, reported values in the range of $2 \mathrm{MPa}$ to $4 \mathrm{MPa}$ for PVAc-adhesive, which contains the values obtained for densified wood (Table 3); while for UF-adhesive the range of values varied from $8 \mathrm{MPa}$ to $9 \mathrm{MPa}$, above the values found for densified wood (Table 3). Furthermore, another study conducted by Moya et al. (2015), confirms the behaviour described, with similar glue line shear strength when using solid wood with PVAc-wood adhesive and a lower value of glue line shear strength when using UF-adhesive. According to Fang et al. (2012) the densification treatment changes the wood's structure due to the temperature and pressure, which both reduce the interlocking surface or mechanical adhesion. Therefore, a reduction in the glue line shear strength in the densified wood should be expected. Additionally, changes in the properties of the wood, such as diffusion, absorption and in the wood's chemical structure can reduce the glue line shear strength.

A. acuminata densified wood obtained the highest average in shear strength (Table 3 ) of the three species. This is attributed to the fact that the densified wood of this species presented more compatibility with the adhesive utilized, resulting in reduced degradation of the structure of the wood during the process. A. acuminata densified wood presented less weight loss $(11,8 \%)$ during stage 1 , with a glue line shear strength of 6,20 MPa (Table 3), compared to the other two species, which showed greater weight loss, approximately $12 \%$, and less glue line shear strength between 2,93 MPa and 3,61 MPa (Table 3).

The wear index value obtained for the densified wood of $A$. acuminata and $V$. guatemalensis was lower in relation to that of $V$. ferruginea wood (Table 3), because the densified wood of $V$. ferruginea is more susceptible to surface wear. This wear index behavior can be explained based on the values of final density and percentage of wood densification. $V$. ferruginea presented a lower percentage of densification, but a final density equal to that of the other two species (Table 2). The wear index of $V$. ferruginea was higher than that of A. acuminata and $V$. guatemalensis (Table 3), suggesting that a low percentage of densification may be associated with greater wood susceptibility to wear. The cause of the decrease in flooring quality may be less formation of covalent and hydrogen bonds and of new cross-linkages and hydrogen bonds between the cellulose and hemicellulose during densification (Dwianto et al. 1999, Navi and Heger 2004) in wood with low percentages of densification, as is the case with $V$. ferruginea in this investigation, because the fibers from one group detach more easily from the other group of fibers.

Regarding the values of residual deformation for the concentrated loading in the indentation test, although no differences were observed in the densified wood of the three species (Table 2), the average deformation obtained in the curves load vs. deformation was greater in $V$. ferruginea densified wood $(8,50 \mathrm{~mm})$ relative to the other two species (A. acuminata with $8,34 \mathrm{~mm}$ and $V$. guatemalensis with 7,54 $\mathrm{mm}$ ) (Figure 1a, Figure $1 \mathrm{~b}$ and Figure $1 \mathrm{c})$. The result of this test indicates that $V$. ferruginea densified wood presents greater deformations for the same load than the other two species (less toughness), confirming the previous affirmation that the densified wood of $V$. ferruginea presents less quality than the other two species due to, as stated above, less formation of covalent and hydrogen bonds and of new cross-linkages of the wood components (Dwianto et al. 1999, Navi and Heger 2004).

Similarly, high values obtained for the residual indentation in the falling ball indentation test and the increased number of samples with moderate and complete damage in the surface indentation test in the densified wood of $V$. ferruginea (Table 3, Figure 3), demonstrate the lower quality of flooring made of this species compared to wood flooring from $A$. acuminata and $V$. guatemalensis.

As previously mentioned, higher wear index, increased residual deformation, high values of residual indentation for the falling ball indentation test and a greater number of samples with moderate and complete damage for the surface indentation test in densified wood from $V$. ferruginea are associated with a lower percentage of densification and high weight loss during stage 1 of the densification process. Thus, since the densified woods of $A$. acuminata and $V$. guatemalensis had better results regarding parameters of quality of flooring and a greater percentage of densification, they could present a better performance in flooring applications. 


\section{CONCLUSIONS}

The thermomechanical densification process, with a 60-minute pre-heating stage 1 and constant temperature during the entire densification process, reduces wood spring-back by $5 \%$ and tends to improve the weight loss due to degradation of some of the wood's components, particularly, hemicellulose degradation with consequent effects on its properties.

The percentage of densification has an effect on the behaviour of the densified wood evaluated as flooring, even if the three species presented statistically similar values of final density. The low percentage of densification and high weight loss of the wood due to temperature and time of exposure in stage 1, cause $V$. ferruginea wood to present greater wear index, higher residual deformation, high values of residual indentation for the falling ball indentation test and a greater number of samples with moderate and complete damage in the surface indentation test than densified wood of $A$. acuminata and $V$. guatemalensis.

\section{ACKNOWLEDGMENTS}

The authors are grateful for the support of the Vicerrectoría de Investigación y Extensión of the InstitutoTecnológico de Costa Rica and of Ethical Forestry S.A., who contributed the materials for this research.

\section{REFERENCES}

ASTM. 2013. Standard test method for strength properties of adhesive bonds in shear by compression loading. ASTM. D905-08. 2013. ASTM International: West Conshohocken, PA, USA. https://doi.org/10.1520/ D0905-08R13

ASTM. 2014. Standard test method for abrasion resistance of organic coatings by the taber abraser. ASTM. D4060-14. 2014. ASTM International: West Conshohocken, PA, USA. https://doi.org/10.1520/D4060-19

ASTM. 2016. Standard test methods for direct moisture content measurement of wood and wood-base materials. ASTM. D4442-16. 2016. ASTM International: West Conshohocken, PA, USA. https://doi.org/10.1520/D4442-16

ASTM. 2017.Standard test methods for simulated service testing of wood and wood-based finish flooring. ASTM. D2394-17. 2017. ASTM International: West Conshohocken, PA, USA. https://doi.org/10.1520/ D2394-17

Blanchet, P.; Beauregard, R.L.; Cloutier, A.; Gendron, G.; Lefebvre, M. 2003. Evaluation of various engineered wood flooring constructions wood cladding in non residential building : finding 'by' and 'for' the design view project. Forest Prod J 53(5): 30-35.

Blanco-Flórez, J.; Silva, J.R.M. Da.; Braga, P.P. De C.; Lima, J.T.; Trugilho, P.F. 2015. Simulação em serviço de pisos de madeira jovem de Tectona grandis. Matéria (Rio de Janeiro) 20(4): 1048-1060. https://doi.org/10.1590/S1517-707620150004.0107

Candelier, K.; Thevenon, M.F.; Petrissans, A.; Dumarcay, S.; Gerardin, P.; Petrissans, M. 2016. Control of wood thermal treatment and its effects on decay resistance: a review. Annals For Sci 73(3): 571-583. https://doi.org/10.1007/s13595-016-0541-X

Darwis, A.; Wahyudi, I.; Dwianto, W.; Cahyono, T.D. 2017. Densified wood anatomical structure and the effect of heat treatment on the recovery of set. J Indian Acad Wood Sci 14(1): 24-31. https://doi.org/10.1007/s13196-017-0184-z

Dwianto, W.; Morooka, T.; Norimoto, M.; Kitajima, T. 1999. Stress relaxation of sugi (Cryptomeria japonica D.Don) wood in radial compression under high temperature steam. Holzforschung 53(5): 541-546. https://doi.org/10.1515/HF.1999.089

Dwianto, W.; Tanaka, F.; Inoue, M.; Norimoto, M. 1996. Crystallinity changes of wood by heat or 
steam treatment. Wood Res 83: 47-49. https://core.ac.uk/download/pdf/39187404.pdf

Fang, C.H.; Blanchet, P.; Cloutier, A.; Barbuta, C. 2012. Engineered wood flooring with a densified surface layer for heavy-duty use. BioRes 7(4): 5843-5854. https://doi.org/10.15376/biores.7.4.5843-5854

Feifel, S.; Stübs, O.; Seibert, K.; Hartl, J. 2015. Comparing wood-polymer composites with solid wood: the case of sustainability of terrace flooring. Eur J Wood Prod 73(6): 829-836. https://doi.org/10.1007/s00107015-0953-6

Inoue, M.; Ogata, S.;Kawai, S.; R, Norimoto, M. 1993. Fixation of compressed wood using melamine-formaldehyde resin. Wood Fiber Sci 25(4): 404-410

Inoue, M.; Sekino, N.; Morooka, T.; Rowell, R.M.; Norimoto, M. 2008. Fixation of compressive deformation in wood by pre-steaming. J Trop For Sci 20(4): 273-281

Jalilzadehazhari, E.; Johansson, J. 2019. Material properties of wooden surfaces used in interiors and sensory stimulation. Wood Mat Sci Eng 14(4): 192-200. https://doi.org/10.1080/17480272.2019.1575901

Kutnar, A.; Kamke, F.A. 2012. Influence of temperature and steam environment on set recovery of compressive deformation of wood. Wood Sci Tech 46(5): 953-964. https://doi.org/10.1007/s00226-011-0456-5

Matsuo, M.; Yokoyama, M.; Umemura, K.; Gril, J.; Yano, K.; Kawai, S. 2010. Color changes in wood during heating: Kinetic analysis by applying a time-temperature superposition method. Appl Physics A: Mat Sci Proc 99(1): 47-52. https://doi.org/10.1007/s00339-010-5542-2

Moya, R. 2018. La producción de madera de especies nativas en plantaciones comerciales: una opción real. Ambientico 267(6): 32-36. http://www.ambientico.una.ac.cr/pdfs/art/ambientico/267_32-36.pdf

Moya, R.; Fallas, R.S.; Bonilla, P.J.; Tenorio, C. 2012. Relationship between wood color parameters measured by the CIELab system and extractive and phenol content in Acacia mangium and Vochysia guatemalensis from fast-growth plantations. Molecules 17(4): 3639-3652. https://doi.org/10.3390/molecules17043639

Moya, R.; Rodríguez-Zúñiga, A.; Vega-Baudrit, J. 2015. Effects of adding multiwall carbon nanotubes on performance of polyvinyl acetate and urea-formaldehyde adhesives in tropical timber species. $J$ Nanomaterials 2015(ID 895650): ID 895650. https://doi.org/10.1155/2015/895650

Moya, R.; Wiemann, M.C.; Olivares, C. 2013. Identificación de especies de árboles en peligro o amenazadas de Costa Rica basada en la anatomía de la madera y fluorescencia. RevBio Trop 61(3): 1133-1156. https://doi.org/10.15517/rbt.v61i3.11909

Navi, P.; Heger, F. 2004. Combined densification and thermo-Hydro-mechanical processing of wood. MRS Bulletin 29(5): 332-336. https://doi.org/10.1557/mrs2004.100

Nölte, A.; Meilby, H.; Yousefpour, R. 2018. Multi-purpose forest management in the tropics: Incorporating values of carbon, biodiversity and timber in managing Tectona grandis (teak) plantations in Costa Rica. For Ecol Manag 422: 345-357. https://doi.org/10.1016/j.foreco.2018.04.036

Nordvik, E.; Schütte, S.; Broman, N.O. 2009. People's perceptions of the visual appearance of wood flooring: A kansei engineering approach. For Prod J 59(11): 67-74. https://doi.org/10.13073/0015-747359.11 .67

Norimoto, M.; Ota, C.; Akitsu, H.; Yamada, T. 1993. Permanent fixation of bending deformation in wood by heat treatment. Wood Res 79: 23-33. https://core.ac.uk/download/pdf/39187454.pdf

Pelit, H.; Budakçı, M.; Sönmez, A. 2016. Densification and heat treatment. BioRes 11(2): 3215-3229. https://bioresources.cnr.ncsu.edu/resources/the-effects-of-densification-and-heat-post-treatment-on-hardnessand-morphological-properties-of-wood-materials/

Perçin, O.; Sofuoglu, S.D.; Uzun, O. 2015. Effects of boron impregnation and heat treatment on some mechanical properties of oak (Quercus petraea Liebl.) wood. BioRes 10(3): 3963-3978.https://doi.org/10.15376/ biores.10.3.3963-3978 
Pohleven, J.; Burnard, M.; Kutnar, A. 2019. Volatile organic compounds emitted from untreated and thermally modified wood- A review. Wood Fiber Sci 51(3): 231-254. https://doi.org/10.22382/wfs-2019-023

Sadatnezhad, S.H.; Khazaeian, A.; Sandberg, D.; Tabarsa, T. 2017. Continuous surface densification of wood: A new concept for large-scale industrial processing. BioRes 12(2): 3122-3132. https://doi.org/10.15376/biores.12.2.3122-3132

Salca, E.A.; Kobori, H.; Inagaki, T.; Kojima, Y.; Suzuki, S. 2016. Effect of heat treatment on colour changes of black alder and beech veneers. J Wood Sci 62(4): 297-304. https://doi.org/10.1007/s10086-016$1558-3$

Sandberg, D.; Haller, P.; Navi, P. 2013. Thermo-hydro and thermo-hydro-mechanical wood processing: An opportunity for future environmentally friendly wood products. Wood Mat Sci Eng 8(1): 64-88. https://doi.org/10.1080/17480272.2012.751935

Serrano, R.; Moya, R. 2011. Procesamiento, uso y mercado de la madera en Costa Rica: aspectos históricos y análisis crítico. Rev For Mesoamericana Kurú 8(21): 1-12. https://revistas.tec.ac.cr/index.php/kuru/ article/view/370

Tenorio, C.; Moya, R. 2020. Effect of thermo-hydro-mechanical densification in the wood properties of three short-rotation forest species in Costa Rica. BioRes 15(4):8065-8064. https://ojs.cnr.ncsu.edu/index.php/ BioRes/article/view/BioRes_15_4_8065_Tenorio_Thermo_Hydro_Mechanical_Densification/8000

Tenorio, C.; Moya, R. 2021. Development of a thermo-hydro-mechanical device for wood densification adaptable to universal testing machines and its evaluation in a tropical species. $J$ Test Eval 49(4). https://doi.org/10.1520/JTE20180760

Tenorio, C.; Moya, R.; Salas, C.; Berrocal, A. 2016. Evaluation of wood properties from six native species of forest plantations in Costa Rica. Bosque 37(1): 71-84. https://doi.org/10.4067/S0717-92002016000100008

Tenorio, C.; Moya, R.; Tommasiello, M. 2020. Density profile and micromorphology variation of densified wood from three fast growth hardwood species in Costa Rica. Wood Fiber Sci 52(3):266-279. https://doi.org/10.22382/wfs-2020-025

United States. Office of Inter-American Affairs. 1943. The Forests of Costa Rica: A General Report on the Forest Resources of Costa Rica- C. A. Merker: Madison, WI. Costa Rica.https://books.google.co.cr/books/ about/The_Forests_of_Costa_Rica.html?id=icX0vQAACAAJ\&redir_esc=y

Zhou, Q.; Chen, C.; Tu, D.; Zhu, Z.; Li, K. 2019. Surface densification of poplar solid wood: Effects of the process parameters on the density profile and hardness. BioRes 14(2): 4814-4831. https://ojs.cnr.ncsu.edu/ index.php/BioRes/article/view/BioRes_14_2_4814_Zhou_Surface_Densification_Poplar_Solid_Wood/6840 